\title{
STUDENTS’ PERCEPTION OF ENGLISH LANGUAGE ANXIETY IN SPEAKING SKILL
}

\author{
Novianty Sunarya ${ }^{1}$, Finasti Pitaloka ${ }^{2}$ \\ ${ }^{1}$ IKIP Siliwangi \\ ${ }^{2}$ IKIP Siliwangi \\ ${ }^{1}$ noviantysunarya45@gmail.com, ${ }^{2}$ pfinasti580@gmail.com
}

\begin{abstract}
Students should learn speaking skill to communicate as one of four major skills in learning English language. However, language anxiety will be experienced by students in learning speaking. The research is aimed to know students' perception of language anxiety in speaking skill. The learners' perception of language anxiety deserve a special mention as it is one of the parties directly involved in learning process. This study explores learners' perceptions of language anxiety in speaking classes at one of the university in Cimahi. This study involved thirty five students from Indonesian Language Department as sample. To collect the data the researchers used numerical likert scale in the questionnaire by Dornyeiand Taguchi (2010: 150) with thirteen questions. From the results, most of students felt the various anxieties when they speak; for example being laugh at by other students when they make mistakes, and most of students feel ashamed if they got bad grades in English.
\end{abstract}

Keywords: Students Perception, Language Anxiety, Speaking

\section{INTRODUCTION}

Speaking is fundamental skill of learning foreign language to communication, to show the ability of language and also to indicate our intellect. Suryani (2015) states that "speaking is used to express meanings so that other people can make sense of them." In other words, speaking is a tool directly come to idea of productive skills, it is an interactive process of convey meaning by expressing feelings, thoughts, ideas, opinion, information to other people to be involved in communication. The needed for good communication skills in English language has created a huge worldwide demand for achieving a good understanding of English around the world. And one of the vital and crucial aspects of learning English has been to develop a good speaking ability.

Many people faced more difficulties in learning English especially in speaking skill as second language. One of the difficulties that often faced by the students while they speak is feeling anxiety. According to Paakki (n.d.) many people report that they can understand a language but they cannot speak it. A special mention is required for language learning contexts as they have usually been subject to anxiety-provoking contexts (Kondo and Ling in Yaikhong \& Usaha, 2012). Given that anxiety arousal is more likely in speaking situations, shedding light on such situations would not be poorly grounded (Hewitt and Stephenson, in Kayaoglu \& Saglame, 2013). As mention above that the anxiety refers to the feeling that makes the student difficult to speak or convey the massege.

The anxiety appears by some factors. As mentioned by Udomkit (2003) in (Kayaoglu \& Saglame, 2013) that the communication anxiety of the basic signal officers in the English classroom at the signal school was caused by the insufficient opportunity for students to participate in classroom communication, lack of confidence when communicating English in 
the classroom, and also by affective factors like interpersonal evaluation, classroom activities and methods, as well as self-esteem. Since the anxiety appears by some factors above that feel by students when speaking, Bunrueng (2008) (in Yaikhong \& Usaha, 2012) investigated levels of anxiety and factors affecting anxiety in taking English for Communication course at LoeiRajabhat University. The findings concerned seven aspects: (1) English for Communication subject; (2) speaking anxiety; (3) listening anxiety; (4) reading anxiety; (5) writing anxiety; (6) teaching-learning activity anxiety, and (7) teaching media and evaluation anxiety. Of these, speaking anxiety was rated at a high level.

From explanation above speaking skill is important to be learned by students, therefore identifying the anxiety as one of difficulties is important as well. The research is aimed to know students' perception of language anxiety they encounter in learning English as a foreign language especially in speaking skill.

\section{METHOD}

Singh (2007) states that "method is a style of conducting a research work which is determined by the nature of problem." In designing any research, s researcher should know well the basic steps of the research process that guide all types of research designs (Kaswan \& Suprijadi, 2013). The research used case study design to find out English language anxiety in speaking class. The participant of this research is college students in last semester of IKIP Siliwangi as population. Then the sample is 35 (thirty five) college students in Indonesian Language and Art Department of IKIP Siliwangi that have learned English in the last semester. The researcher used a questionnaire by (Dornyei \& Taguchi, 2010) as the instrument. The participants were given thirteen questions related with the students anxiety in speaking class. This scale is used to identify someone perception, response or opinion. There are five statements that can be used as indicators to find the perseption of the students namely strongly disagree, disagree, slightly disagree, slightly agree, agree and strongly agree.

\section{RESULTS AND DISCUSSION}

\section{Results}

This study analyzed the students' perception of English language anxiety in speaking classes. In this study, students were asked thirteen questions. The study results are based on answers from questionnaire shared to participants. The data would be described as follows.

Table 1. Questionnaire number 1

\begin{tabular}{|c|c|c|c|c|c|c|}
\hline \multirow[b]{2}{*}{ Statement } & \multicolumn{6}{|c|}{ Students' Response } \\
\hline & $\begin{array}{l}\text { Strongly } \\
\text { disagree }\end{array}$ & Disagree & $\begin{array}{l}\text { Slightly } \\
\text { disagree }\end{array}$ & $\begin{array}{l}\text { Slightly } \\
\text { agree }\end{array}$ & Agree & $\begin{array}{l}\text { Strongly } \\
\text { agree }\end{array}$ \\
\hline $\begin{array}{l}\text { Studying English is } \\
\text { important to me, because I } \\
\text { would feel ashamed if I got } \\
\text { bad grades in English. }\end{array}$ & 1 & 2 & 7 & 7 & 12 & 6 \\
\hline
\end{tabular}

Based on the table above, one $(2.85 \%)$ student strongly disagree that studying English is important because it would make students' feel ashamed if the students' got bad grades in English, two (5.71\%) students disagreed, seven (20\%) students slightly disagreed, seven 
(20\%) students slightly, twelve (34.3\%) students agreed and six (17.1\%) students strongly agreed.

Table 2. Questionnaire number 2

\begin{tabular}{lllllll}
\hline \multirow{2}{*}{ Statement } & \multicolumn{2}{l}{ Students' Response } & & & \\
\cline { 2 - 7 } & $\begin{array}{l}\text { Strongly } \\
\text { disagree }\end{array}$ & Disagree & $\begin{array}{l}\text { Slightly } \\
\text { disagree }\end{array}$ & $\begin{array}{l}\text { Slightly } \\
\text { agree }\end{array}$ & $\begin{array}{c}\text { Agree } \\
\text { Strongly } \\
\text { agree }\end{array}$ \\
\hline $\begin{array}{l}\text { Studying English is important } \\
\text { to me because, if I don't have } \\
\text { knowledge of English, I'll be } \\
\text { considered a weak learner. }\end{array}$ & 2 & 2 & 7 & 10 & 9 & 5 \\
\hline
\end{tabular}

Based on the table above, two (5.71\%) students strongly disagree that studying English is important because if the students don't have knowledge of English, it will be make students considered a weak learner, two $(5.71 \%)$ students, seven (20\%) students slightly disagreed, ten (28.6\%) students slightly agree, nine (25.7\%) students agreed and five (14.28\%) students strongly agreed.

Table 3. Questionnaire number 3

\begin{tabular}{lllllll}
\hline \multirow{2}{*}{ Statement } & \multicolumn{2}{l}{ Students' Response } & & \\
\cline { 2 - 7 } & $\begin{array}{l}\text { Strongly } \\
\text { disagree }\end{array}$ & Disagree & $\begin{array}{l}\text { Slightly } \\
\text { disagree }\end{array}$ & $\begin{array}{l}\text { Slightly } \\
\text { agree }\end{array}$ & $\begin{array}{c}\text { Agree } \\
\text { Strongly } \\
\text { agree }\end{array}$ \\
\hline $\begin{array}{l}\text { Studying English is important to } \\
\text { me because I don't like to be } \\
\begin{array}{l}\text { considered a poorly educated } \\
\text { person. }\end{array}\end{array}$ & 3 & 7 & 10 & 10 & 4 \\
\hline
\end{tabular}

Based on the table above, one (2.85\%) student was strongly disagree that Studying English is important, because the students did not like to be considered a poorly educated person, three $(8.57 \%)$ students disagreed, seven (20\%) students slightly disagreed, ten (28.6\%) students slightly agree, ten $(28.6 \%)$ students agreed that and four $(11.4 \%)$ students strongly agreed.

Table 4. Questionnaire number 4

\begin{tabular}{lllllll}
\hline \multirow{2}{*}{ Statement } & \multicolumn{2}{l}{ Students' Response } & & & \\
\cline { 2 - 7 } & $\begin{array}{l}\text { Strongly } \\
\text { disagree }\end{array}$ & Disagree & $\begin{array}{l}\text { Slightly } \\
\text { disagree }\end{array}$ & $\begin{array}{l}\text { Slightly } \\
\text { agree }\end{array}$ & Agree & $\begin{array}{l}\text { Strongly } \\
\text { agree }\end{array}$ \\
\hline $\begin{array}{l}\text { I get nervous and confused when } \\
\begin{array}{l}\text { I am speaking in my English } \\
\text { class. }\end{array}\end{array}$ & 3 & 2 & 9 & 9 & 7 & 5 \\
\hline
\end{tabular}

Based on the table above, three $(8.57 \%)$ students was strongly disagree that the students would get nervous and confused when speak in English class, two (5.71\%) students disagreed, nine $(25.7 \%)$ students slightly disagreed, nine $(25.7 \%)$ students slightly agree, seven $(20 \%)$ students agreed and five $(14.28 \%)$ students strongly agreed. 
Table 5. Questionnaire number 5

\begin{tabular}{lllllll}
\hline \multirow{2}{*}{ Statement } & \multicolumn{2}{l}{ Students' Response } & & & \\
\cline { 2 - 7 } & $\begin{array}{l}\text { Strongly } \\
\text { disagree }\end{array}$ & Disagree & $\begin{array}{l}\text { Slightly } \\
\text { disagree }\end{array}$ & $\begin{array}{l}\text { Slightly } \\
\text { agree }\end{array}$ & Agree & $\begin{array}{l}\text { Strongly } \\
\text { agree }\end{array}$ \\
\hline $\begin{array}{l}\text { How nervous and confused do } \\
\text { you get when you are speaking } \\
\text { in your English class? }\end{array}$ & 2 & 3 & 4 & 12 & 11 & 3 \\
\hline
\end{tabular}

Based on the table above, two $(5.71 \%)$ students was strongly disagree that the students feel nervous and confused when speak in English class, three $(8.57 \%)$ students disagreed, four $(11.4 \%)$ students slightly disagreed, twelve (34.3\%) students slightly agree, eleventh $(31.4 \%)$ students agreed and three $(8.57 \%)$ students strongly agreed.

Table 6. Questionnaire number 6

\begin{tabular}{lllllll}
\hline \multirow{2}{*}{ Statement } & \multicolumn{2}{l}{ Students' Response } & & & \\
\cline { 2 - 7 } & $\begin{array}{l}\text { Strongly } \\
\text { disagree }\end{array}$ & Disagree & $\begin{array}{l}\text { Slightly } \\
\text { disagree }\end{array}$ & $\begin{array}{l}\text { Slightly } \\
\text { agree }\end{array}$ & $\begin{array}{c}\text { Agree } \\
\text { Strongly } \\
\text { agree }\end{array}$ \\
\hline $\begin{array}{l}\text { How afraid are you that other } \\
\text { students will laugh at you when } \\
\text { you speak English? }\end{array}$ & 1 & 5 & 7 & 7 & 12 & 3 \\
\hline
\end{tabular}

Based on the table above, one $(2.85 \%)$ student was strongly disagree that the students will afraid if the other students will laugh when the students speak English, five (14.28\%) students disagreed that, seven (20\%) students slightly disagreed, seven (20\%) students slightly, twelve (34.3\%) students agreed and three (8.57\%) students strongly agreed.

Table 7. Questionnaire number 7

\begin{tabular}{lllllll}
\hline \multirow{2}{*}{ Statement } & \multicolumn{2}{l}{ Students' Response } & & \\
\cline { 2 - 7 } & $\begin{array}{l}\text { Strongly } \\
\text { disagree }\end{array}$ & Disagree & $\begin{array}{l}\text { Slightly } \\
\text { disagree }\end{array}$ & $\begin{array}{l}\text { Slightly } \\
\text { agree }\end{array}$ & Agree & $\begin{array}{l}\text { Strongly } \\
\text { agree }\end{array}$ \\
\hline $\begin{array}{l}\text { I would feel uneasy speaking } \\
\text { English with a native speaker. }\end{array}$ & 6 & 2 & 11 & 6 & 7 & 3 \\
\hline
\end{tabular}

Based on the table above, six $(17.1 \%)$ students was strongly disagree that the students would feel uneasy speak English with a native speaker, two (5.7\%) students disagreed, eleventh $(31.4 \%)$ students slightly, six (17.1\%) students slightly, seven (20\%) students agreed, and three $(8.57 \%)$ students strongly agreed.

Table 8. Questionnaire number 8

\begin{tabular}{lllllll}
\hline \multirow{2}{*}{ Statement } & \multicolumn{2}{l}{ Students' Response } & & & \\
\cline { 2 - 7 } & & $\begin{array}{l}\text { Strongly } \\
\text { disagree }\end{array}$ & Disagree & $\begin{array}{l}\text { Slightly } \\
\text { disagree }\end{array}$ & $\begin{array}{l}\text { Slightly } \\
\text { agree }\end{array}$ & $\begin{array}{c}\text { Agree } \\
\text { Strongly } \\
\text { agree }\end{array}$ \\
\hline $\begin{array}{l}\text { How uneasy would you feel } \\
\text { speaking English with a native } \\
\text { speaker? }\end{array}$ & 6 & 3 & 8 & 10 & 7 & 1 \\
\hline
\end{tabular}


Based on the table above, six (17.1\%) students was strongly disagree that the students would feel uneasy when speak English with a native speaker, three $(8.57 \%)$ students disagreed, eight $(22.9 \%)$ students slightly disagreed, ten $(28.6 \%)$ students slightly agree, seven $(20 \%)$ students agreed and one $(2.85 \%)$ student strongly agreed.

Table 9. Questionnaire number 9

\begin{tabular}{|c|c|c|c|c|c|c|}
\hline \multirow[b]{2}{*}{ Statement } & \multicolumn{6}{|c|}{ Students' Response } \\
\hline & $\begin{array}{l}\text { Strongly } \\
\text { disagree }\end{array}$ & Disagree & $\begin{array}{l}\text { Slightly } \\
\text { disagree }\end{array}$ & $\begin{array}{l}\text { Slightly } \\
\text { agree }\end{array}$ & Agree & $\begin{array}{l}\text { Strongly } \\
\text { agree }\end{array}$ \\
\hline $\begin{array}{l}\text { If I met an English native } \\
\text { speaker, I would feel nervous. }\end{array}$ & 4 & 7 & 7 & 10 & 6 & 1 \\
\hline
\end{tabular}

Based on the table above, four (11.4\%) students was strongly disagree that the students would feel nervous when met with an English native speaker, seven (20\%) students disagreed, seven (20\%) students slightly disagreed, ten (28.6\%) students slightly agree, six $(17.1 \%)$ students agreed and one (2.9\%) student strongly agreed.

Table 10. Questionnaire number 10

\begin{tabular}{lllllll}
\hline \multirow{2}{*}{ Statement } & \multicolumn{2}{l}{ Students' Response } & & \\
\cline { 2 - 7 } & $\begin{array}{l}\text { Strongly } \\
\text { disagree }\end{array}$ & Disagree & $\begin{array}{l}\text { Slightly } \\
\text { disagree }\end{array}$ & $\begin{array}{l}\text { Slightly } \\
\text { agree }\end{array}$ & Agree & $\begin{array}{l}\text { Strongly } \\
\text { agree }\end{array}$ \\
\hline $\begin{array}{l}\text { I would get tense if a foreigner } \\
\text { asked me for directions in } \\
\text { English. }\end{array}$ & 3 & 3 & 7 & 11 & 9 & 2 \\
\hline
\end{tabular}

Based on the table above, three (8.57\%) students was strongly disagree that the students would get tense if a foreigner asked for directions in English, three (8.57\%) students disagreed that, seven (20\%) students slightly disagreed, eleventh $(31.4 \%)$ students slightly agree, nine $(25.7 \%)$ students agreed and two $(5.71 \%)$ students strongly agreed.

Table 11. Questionnaire number 11

\begin{tabular}{lllllll}
\hline \multirow{2}{*}{ Statement } & \multicolumn{2}{l}{ Students' Response } & & & \\
\cline { 2 - 7 } & & $\begin{array}{l}\text { Strongly } \\
\text { disagree }\end{array}$ & Disagree & $\begin{array}{l}\text { Slightly } \\
\text { disagree }\end{array}$ & $\begin{array}{l}\text { Slightly } \\
\text { agree }\end{array}$ & $\begin{array}{c}\text { Agree } \\
\text { Strongly } \\
\text { agree }\end{array}$ \\
\hline $\begin{array}{l}\text { How tense would you get if a } \\
\text { foreigner asked you for } \\
\text { directions in English? }\end{array}$ & & 4 & 7 & 13 & 5 & 3 \\
\hline
\end{tabular}

Based on the table above, three $(8.57 \%)$ students was strongly disagree about how big tense would the students get if a foreigner asked for directions in English, four (11.4\%) students disagreed, seven (20\%) students slightly disagreed, thirteen $(37.1 \%)$ students slightly agree, five $(14.28 \%)$ students agreed and three $(8.57 \%)$ students strongly agreed.

Table 12. Questionnaire number 12

\begin{tabular}{|c|c|c|c|c|c|}
\hline \multirow[b]{2}{*}{ Statement } & \multicolumn{5}{|l|}{ Students' Response } \\
\hline & $\begin{array}{ll}\text { Strongly } & \text { Disagree } \\
\text { disagree } & \end{array}$ & $\begin{array}{l}\text { Slightly } \\
\text { disagree }\end{array}$ & $\begin{array}{l}\text { Slightly } \\
\text { agree }\end{array}$ & Agree & $\begin{array}{l}\text { Strongly } \\
\text { agree }\end{array}$ \\
\hline
\end{tabular}


How afraid are you of sounding stupid in English because of the 3 mistakes you make?

Based on the table above, three $(8.57 \%)$ students was strongly disagree about how afraid the students would sound stupid in English if the students were make mistakes, nine $(25.7 \%)$ students disagreed, ten (28.6\%) students slightly disagreed, four (11.4\%) students slightly agree, eight (22.8\%) students agreed and one (2.85\%) student strongly agreed.

Table 13. Questionnaire number 13

\begin{tabular}{lllllll}
\hline & $\begin{array}{l}\text { Strongly } \\
\text { disagree }\end{array}$ & Disagree & $\begin{array}{l}\text { Slightly } \\
\text { disagree }\end{array}$ & $\begin{array}{l}\text { Slightly } \\
\text { agree }\end{array}$ & Agree & $\begin{array}{l}\text { Strongly } \\
\text { agree }\end{array}$ \\
\hline $\begin{array}{l}\text { How worried are you that } \\
\text { other speakers of English }\end{array}$ & 7 & 5 & 8 & 7 & 7 & 1 \\
$\begin{array}{l}\text { would find your English } \\
\text { strange? }\end{array}$ & & & & & & \\
\hline
\end{tabular}

Based on the table above, seven (20\%) students was strongly disagree that the students would worried if the other speakers of English would find the English strange when speak, five $(14.28 \%)$ students, eight $(22.9 \%)$ students slightly disagreed, seven (20\%) students slightly agree, seven (20\%) students agreed, and one (2.85\%) student strongly agreed.

\section{Discussion}

The research is aimed to know students' perception of language anxiety in learning English as a foreign language especially in speaking skill. From the result above it can be showed that most of students strongly agree with the question "Studying English is important to me, because I would feel ashamed if I got bad grades in English" there are six students or 17.1\%. The question which have most agree is the question "Studying English is important to me, because I would feel ashamed if I got bad grades in English" and "How afraid are you that other students will laugh at you when you speak English?" there are twelve students or $34.3 \%$. The question that have the most slightly agree is the question "How tense would you get if a foreigner asked you for directions in English?" there are thirteen students or 37,1\%. The question that have most slightly disagree is the question "would feel uneasy speaking English with a native speaker" there are eight students or $22.9 \%$. The question that have the most disagree is the question "How afraid are you of sounding stupid in English because of the mistakes you make?" there are nine students or 25.7\%.The last the question that have the most strongly disagree is the question "How worried are you that other speakers of English would find your English strange?" there are seven students or $20 \%$. Therefore, it can be assumed that students feel ashamed if got bad grades in English, and students feel anxious if the other students will laugh when speak English.

\section{CONCLUSION}

In the present study indicated students' perception will feel anxiety about speaking skill when the students learn English as a foreign language. From the result above that most of the students agree that "studying English is important because it would make students' feel ashamed if the students' got bad grades in English" they would feel anxiety if the students got bad grades in English and did not have knowledge of English. And the least chosen question is "If I met an English native speaker, I would feel nervous." In addition, most of the students 
also felt the various anxieties when they speak, this is seen from the question "How afraid are you that other students will laugh at you when you speak English?" with 34.3\% response. Therefore, it can be assumed that students feel ashamed if got bad grades in English, and students anxiety if the other students will laugh when speak English.

\section{ACKNOWLEDGMENTS}

The researchers greatest appreciation to IKIP Siliwangi, The Head of English Education Study Program. The researchers also want to deliver our sincere thank to our advisor, who already gave us suggestions and guidance which are useful to finish our journal. The researchers also thank to all lecturers in English Education Study Program for the time and share your knowledge. 
288 Sunarya, Pitaloka. Students' Perception Of English Language Anxiety In Speaking Skill

\section{REFERENCES}

Dornyei, Z., \& Taguchi, T. (2010). Questionnaires in Second Language Research: Construction, Administration, and Processing. New York: Routledge.

Kaswan, \& Suprijadi, D. (2013). Research in English Language Education. Bandung: Putra Praktisi.

Kayaoglu, M. ., \& Saglame, H. (2013). students' Perception of language anxiety in speaking classes. Tarih Kultur ve Sanat Arastirmalari Dergisi.

Paakki, H. (n.d.). Difficulties in Speaking English and Perceptions of Accents A Comparative Study of Finnish and Japanese Adult Learners of English.

Singh, K. (2007). Quantitative Social Research Methods. New Delhi: Sage Publications Pvt Ltd.

Suryani, L. (2015). THE EFFECTIVENESS OF ROLE PLAY IN TEACHING SPEAKING. ELTIN JOURNAL, Journal of English Language Teaching in Indonesia, 3(2). https://doi.org/10.22460/ej.v3i2p\%p.127

Yaikhong, K., \& Usaha, S. (2012). A measure of EFL public speaking class anxiety: Scale development and preliminary validation and reliability. English Language Teaching, 5(12), 23-35. https://doi.org/10.5539/elt.v5n12p23 